\title{
Yöneticilerin Liderlik Davranışlarının Çalışanların Pozitif Psikolojik Sermaye Seviyelerine Etkisi ${ }^{a}$
}

\author{
Gamze Ayb,c, Cansu Bozdoğand
}

Özet

Modern yönetim çağında, işletmelerin insan kaynağını sermayeye dönüştürebilmeleri yeni yönetim tarzlarını gündeme getirmektedir. Alanyazın taraması sonucunda bu çalışmada yöneticilerin liderlik davranışlarının çalışanların pozitif psikolojik sermaye seviyeleri üzerindeki etkisinin belirlenmesi amaçlanmıştır. Gaziantep ilinde 2. organize sanayi bölgesinde çalışanlar araştırmanın evrenini oluşturmaktadır. Anket formu Organize Sanayi Bölgesi Müdürlüğü aracılığıyla çalışanlara e-posta ile gönderilmiştir. 161 anketten toplanan veriler değerlendirilmiştir. Veriler anket yöntemi ile liderlik davranışları ve pozitif psikolojik sermaye ölçekleri kullanılarak toplanmıştır. Liderlik davranışları ve psikolojik sermaye ölçeklerinin doğrulayıcı faktör analizi sonucunda geçerli olduğu ve ölçeklerin Cronbach alfa güvenilirlik katsayısının 0,90 üzerinde olduğu tespit edilmiştir. Yöneticilerin liderlik davranışlarının çalışanların psikolojik sermaye düzeyleri üzerine etkisi olduğu sonucuna ulaşılmıştır. Çalışanların psikolojik sermaye düzeyleri yüksektir ve yöneticiler üretim odaklı liderlik davranışlarını daha fazla göstermektedir.
Anahtar Kelimeler

Liderlik Davranışları

Psikolojik Sermaye

Çalışanlar

Makale Hakkında

Geliş Tarihi: 06.01.2020

Kabul Tarihi: 25.12.2020

Doi: $10.18026 /$ cbayarsos.671187

\section{Effects of Managers' Leadership Behaviors on Positive Psychological Capital Levels of Employees}

\begin{abstract}
In the era of modern management, businesses can convert human resources into capital occur in new management styles. As a result of the literature review, this study aimed to determine the effect of managers' leadership behaviors on positive psychological capital levels of employees. The workers in the 2nd organized industrial zone in the province of Gaziantep constitute the universe of research. A questionnaire form was sent to the employees via the Organized Industrial Zone Directorate by e-mail. The collected data from 161 questionnaires were evaluated. Data were collected using the survey method, Leadership Behaviors and Positive Psychological Capital scales. It was determined that leadership behaviors and psychological capital scales were valid as a result of the confirmatory factor analysis and the Cronbach alpha reliability coefficient of the scales was above 0.90 . Leadership behaviors of managers are the result of employees' influence on psychological capital levels. The psychological capital levels of the employees are high and the managers show more production-oriented leadership behaviors.
\end{abstract}

Keywords

Leadership Behaviors

Psychological Capital

Employees

About Article

Received: : 06.01.2020

Accepted: 25.12.2020

Doi: $10.18026 /$ cbayarsos.671187

\footnotetext{
a Bu çalışma, Hitit Üniversitesinde düzenlenen 16. Ulusal Büro Yönetimi ve Sekreterlik Kongresi'nde bildiri olarak sunulmuştur.

b İletişim Yazarı: drgamzeay@gmail.com

c Dr. Öğr. Gör., Eskişehir Osmangazi Üniversitesi Sağlık Hizmetleri Meslek Yüksekokulu, drgamzeay@ gmail.com, Orcid: 0000-0003-1299-8552

d Öğr. Gör., Eskişehir Osmangazi Üniversitesi Sağlık Hizmetleri Meslek Yüksekokulu, cozturk@ ogu.edu.tr, Orcid: 0000-0002-8146-7555
} 


\section{Giriş}

Yapılan birçok akademik araştırmada liderlik davranışlarının örgüt çalışanlarının performansında ve psikolojik kaynakları üzerinde etkisi olduğu açıklanmaktadır. Araştırma sonuçları, psikolojik sermaye ve arzu edilen çalışan tutumları (iş doyumu, örgütsel bağlılık, psikolojik mutluluk), arzu edilen çalışan davranışları (vatandaşlık) ve performans arasında anlamlı ve pozitif yönde ilişkiler olduğunu göstermektedir (Avey, Reichard, Luthans ve Mhatre, 2011: 127). Organizasyonların büyümesi, lidere düşen görevlerin artması, örgütsel performans ve kârlılığın artırılmak istenmesi gibi nedenler çalışanların liderlik sürecine dâhil edilmesini gündeme getirmektedir (Tabak, Sığrı ve Türköz, 2013: 214).

Yapılan araştırmalar liderlik davranışlarının; örgütün yapısı, işleyişi ve kültürü üzerinde önemli etkileri olduğu gibi takipçilerin üzerinde de önemli etkilere sahip olduğunu göstermektedir (A ğca ve Döven, 2016: 859). Astların üstlere bağımlı olduğu, liderlerin astların davranışları üzerinde önemli bir etkisi olduğu ifade edilmektedir (Detert ve Trevino, 2010: 250). İşletmelerdeki yöneticilerin farklı liderlik davranışları vardır. Olumlu bir örgüt iklimi yaratarak çalışanlardan en yüksek verimi bekleyen yöneticiler, çalışanlarının güçlü ve güçsüz yanlarını, kişiliklerine bağlı olarak pozitif ve negatif davranış değişkenlerini anlamak, bunların işlerine etkisini belirleyerek "psikolojik sermayelerine" yatırım yapmaları gerekmektedir (Keleş, 2011: 349).

Bandura'nın (1977) sosyal öğrenme teorisine göre, bireyler dikkat süreçlerinden sonra rol modellerine güvenerek davranışlarına katılırlar ve onları gözlemleyerek öğrenirler. Örgütlerde, denetim otoriteleri genellikle takipçilerinden daha yüksek bir statüye sahip olmasından dolayı, çalışanlara hangi modelin potansiyel olarak uygun olduğuna dair etkili bilgi kaynağ1 sağlar (Bandura ve Walters, 1977; Walumbwa vd., 2010: 940-941).

1999 yılında pozitif psikoloji hareketiyle başlayan değişim, çalışanların işlerinden beklentilerini etkilemiştir. Daha mutlu olma isteğini iş yaşamında karşılamaya çalışanların gereksinimlerini geleneksel psikoloji yaklaşımları ya da örgütsel araçlarla karşılamak güçleşmiştir (Seligman, 2002: 3; Özer vd., 2013: 438). Pozitif psikoloji literatürünün ortaya çıkışı, psikolojik güçlerin ve kaynakların tutumları şekillendirebileceği ve kişinin ilişkileri, esenliği, atletik ve akademik başarısı gibi çeşitli yaşam alanlarında ve iş yeri çıktılarında istenen sonuçlara götürebileceği fikrini güçlendirmiştir (Luthans vd., 2014: 192).

Psikolojik Sermaye, "bir bireyin pozitif psikolojik gelişimsel durumu” olarak tanımlanmaktadır (Luthans, Youssef ve Avolio, 2007b). Liderlik becerileri ve nitelikleri, sadece firmaların başarısı için değil, aynı zamanda bireylerin terfi edilebilirliği ve kariyer başarısı için de örgütsel öneme sahiptir. Hem liderlik araştırmacıları hem de uygulayıcılar, etkili önderlikte kilit rol oynadığını düşündüğü iyimserlik, umut, özyeterlilik ve psikolojik dayanıklılık gibi özelliklere daha yoğun bir şekilde odaklanmaya başlamışlardır. Nebraska Üniversitesi Global Liderlik Enstitüsü'ndeki Fred Luthans ve meslektaşları tarafından ilk kez işyerinde uygulanan iyimserlik, umut, özgüven ve dayanıklılık gibi faktörlerin pozitif yönlü psikolojik kapasiteler olarak tanımlanarak performans gelişimi için ölçülebilir, geliştirilebilir ve yönetilebilir olduğunu açıklamışlardır (Peterson, Balthazard ve Waldman ve Thatcher, 2008:342).

Psikolojik sermayenin uzun vadeli, benzersiz, kümülatif, birbirine bağlı ve yenilenebilir özelliklerinden dolayı rekabet avantajı sağlayacağı ifade edilmektedir (Pitichat, Reichard, KeaEdwards, Middleton ve Norman,2018: 47). Yüksek düzeyde psikolojik sermaye sahibi olan liderler, çalışanlarla günlük etkileşimlerinde çok fazla güven, iyimserlik, umut ve esneklik 
sergileyebilir ve bu da çalışma ekibinde olumlu duygular uyandırmaktadır ( $\mathrm{Xu}$, Liu ve Chung, 2017: 973).

Bir kişinin eserinin niceliği ve kalitesi aynı zamanda psikolojik sermayelerine, yani üretkenliği etkileyen kişilik özelliklerine de bağlıdır. Hayat Boyu Kalkınma Teorisinin kurucusu Erikson, psikolojik bakımdan sağlıklı bireylerin en üretken olacağını savunmuştur (Goldsmith, Darity ve Veum 1998: 15). Psikolojik sermaye, zayıf ve olumsuz davranış eğilimlerinden ziyade, çalışanların güç ve erdemlerinden yararlanmayı ve çalışan davranışları, duygularında arzu edilen değiş̧iklikleri gerçekleştirmek için bu güçlü yönlerini geliştirmeyi vurgulayan örgütsel davranış yaklaşımıdır (Luthans, Avolio, Avey, ve Norman, 2007a; aktaran Krasikova vd., 2015: 281). Bu örgütsel davranış yaklaşımında açılanan çalışanın üretkenliği, davranışlarını etkileyen psikolojik kaynaklarının güçlenmesinde lider özelliklerinin etkisi olabileceği düşünülmektedir. Buradan hareketle, liderin göstereceği davranışların çalışanların psikolojik sermaye düzeyleri üzerinde etkisinin belirlenmesi amaçlanmıştır. Alanyazında yapılan sınırlı sayıda araştırmalar incelenmiştir. Araştırma sonucunda Türkçe uyarlaması yapılan psikolojik sermaye ve liderlik davranışları ölçeklerinin yapı geçerlilikleri tekrar doğrulanmıştır. Yapılan regerasyon analizi sonucunda yöneticilerin liderlik davranışlarının çalışanların psikolojik sermaye düzeyleri üzerine etkisi olduğu belirlenmiştir. Üretim odaklı liderlik davranışlarının daha yüksek olduğu sonucuna ulaşılmıştır. Çalışmanın ana kaynaklarından Ekvall ve Arvonen, 1991 çalışmasına göre farklı sonuç elde edilmesinden dolayı çalışmanın özgün nitelikte olduğu söylenebilir.

\section{Kavramsal Çerçeve}

\section{Psikolojik Sermaye}

Psikolojik sermaye kavramsal olarak Luthans ve meslektaşları tarafından, umut, iyimserlik, öz yeterlilik ve psikolojik dayanıklılığın dört pozitif psikolojik kaynağından oluşan bir kavram olarak tanımlanmıştır (Luthans ve Youssef 2004; Luthans vd., 2007b). Psikolojik sermayenin kapsamlı tanımı şu şekildedir:

... (1) zorlu görevlerde başarılı olmak için gerekli çabayı sürdürecek ve bunları yerine getirecek bir güven yani öz yeterlilik sahibi olan; (2) şimdi ve gelecekte başarılı olma konusunda olumlu bir atıf (iyimserlik) yaratmak; (3) hedefler için azim ve gerektiğinde başarmak için hedeflerde (umut) yön değiştirme ve (4) sorunlar ve zorluklarla karşılaştı̆̆ında, başarıyı elde etmek için sürdürülebilir kapasitedir (esneklik/dayanıklılık). (Luthans vd., 2007b: 3; Avey vd., 2011: 128)

Psikolojik sermaye, son yıllarda pozitif psikoloji literatüründen yararlandı ve insan kaynakları yönetimi ve örgütsel davranış alanlarında büyük ilgi görmüştür (Luthans ve Avey, 2014), Psikolojik sermaye ile performans ve iş tatmini arasında pozitif bir ilişki olduğunu (Luthans vd., 2007a), psikolojik sermayenin yenilikçi iş performansı ile pozitif ve iş stresi ile negatif ilişkili olduğunu (Abbas ve Raja, 2015), daha yüksek düzeyde psikolojik sermayeye sahip olanların ruh sağlığı sorunları ve madde bağımlılığı teşhisi alma olasılığının daha düşük olduğu (Krasikova vd., 2015), çalışanların psikolojik sermaye düzeylerinin iş doyumunu geliştirici etkisi, destekleyici örgüt ikliminin daha pozitif algılandığı şartlarda daha yüksek olacağ1 (Özer, Topaloğlu ve Özmen, 2013: 444), psikolojik sermayenin otantik liderlik, psikolojik iklim ve takım bağl1lığı arasında önemli ölçüde güçlü bir pozitif ilişki (Munyaka 
vd., 2017), olduğu araştırmalar sonucunda tespit edilmiştir. Şekil 1'de gösterildiği gibi psikolojik sermaye yapısını en iyi açıklayan psikolojik niteliklerin umut, psikolojik dayanıklılık, iyimserlik ve öz yeterlilik olduğu öne sürülmektedir (Luthans ve Youssef, 2004: 151-152; Çetin ve Basım, 2012).

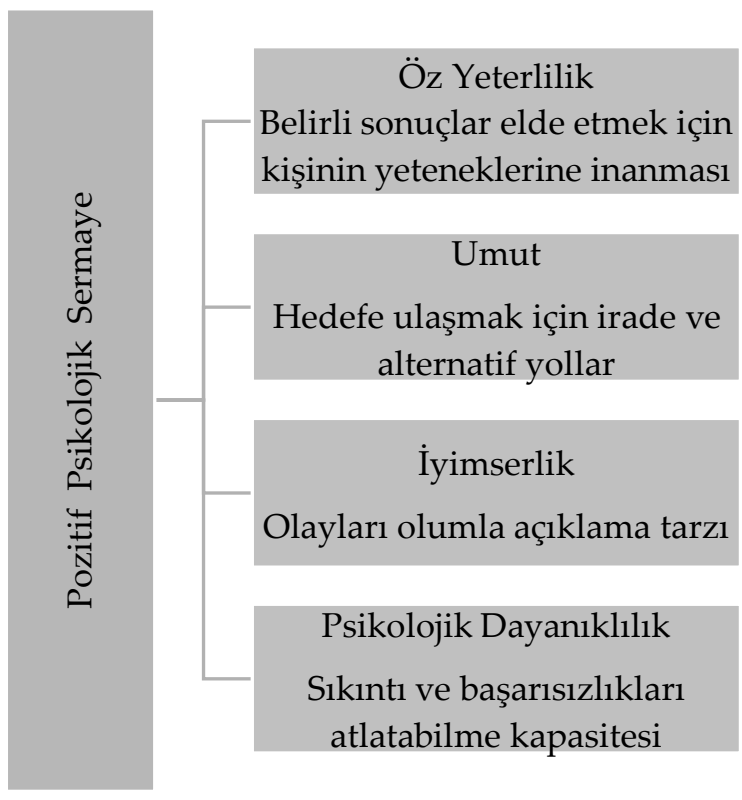

Şekil 1. Psikolojik Sermaye Boyutları (Luthans ve Youssef, 2004: 152).

a. Öz yeterlilik, Albert Bandura'nın teorisinden yararlanılarak; kişinin belirli bir bağlamda belirli bir eylem planını yürütmek için gerekli motivasyonu, bilişsel kaynakları ve gerekli eylemleri harekete geçirme kabiliyetine güvenmesi olarak tanımlanmaktadır. Kendi kendine yeten kişiler (kendine güvenen) zorlu görevler ve çabalar seçer, hedeflerine başarılı bir şekilde ulaşmak için motivasyonu ve çabayı arttırır ve engellerle karşı karşıya kaldıklarında sebat ederler (Luthans ve Youssef, 2004: 153).

b. Umut boyutuna pozitif psikolog C. Rick Snyder'in çalışmasında değinilmektedir. Umut, değerli amaçlar belirleyebilme ve bu amaçları elde etmede kişinin engellerin üstesinden gelebilme inancını kapsayan motivasyonel bir durumdur (Çetin ve Basım, 2012: 123). Yüksek umut sahibi olanlar, hedeflerine ulaşmalarına yönelik alternatif yollar üretme imkânı sağlayan, istedikleri şeyleri elde etme yollarını geliştirme yeteneğine sahip olma duygusuyla motive edilirler (Luthans ve Youssef, 2004: 153).

c. İyimserlik, Seligman ve diğerleri tarafından pozitif psikoloji hareketiyle araştırılmıştır. İyimserlik, olumlu olayları içsel, kalıcı ve yaygın nedenlere; olumsuz olayları dışsal, geçici ve durumsal olaylara bağlayan olumlu bir açılayıcı stil içermektedir. İyimserler başarının tekrarlanabileceğini ve kontrol edilebileceğini düşünmektedir (Sweetman vd., 2011: 6). Kişinin amacına ulaşmak için ısrarcı davranmasını sağlayacak şekilde hayatta başına iyi şeylerin geleceğine dair genellenmiş bir beklenti olarak ifade edilmektedir (Keleş, 2011: 347). Bireylerin yaşamlarındaki olumlu olaylar için itibar kazanmalarını, özgüvenlerini ve morallerini arttırmalarını sağlamaktadır. Kendilerini 
olumsuz yaşam olaylarından uzaklaştırmaya, depresyon, kendini suçlama ve umutsuzluğa karşı koruyabilmelerini sağlamaktadır (Luthans ve Youssef, 2004: 153).

d. Psikolojik dayanıklılık; terslik, çatışma ve başarısızlık, hatta olumlu olaylar, gelişim ve artan sorumlulukla baş edebilmek için geliştirilebilir kapasite olarak tanımlanmaktadır (Youssef ve Luthans, 2012: 5-6; Luthans ve Youssef, 2004: 154). Esneklik, bireysel ve çevresel koruyucu mekanizmaların varlıkları iyileştirerek ve bireyler ve çevreleri içindeki risk faktörlerini azaltarak çalışmasını sağlamaktadır (Luthans ve Youssef, 2004: 154). Psikolojik sermaye, performansı pozitif yönde etkileyen, bireyin kendi potansiyelini fark etmesiyle kendini geliştirme fırsatı yaratan bir yaklaşım sunmaktadır (Keser ve Kocabaş, 2014: 7).

Pozitif psikoloji yaklaşımı, sadece zihinsel hastalıkları iyileştirmeye dönük tekil vurgudan uzaklaşmaktadır. İnsanların hayatlarını daha üretken ve değerli kılmaktadır ve insan potansiyelini gerçekleştirme misyonuna yönlendirmektedir. Amerikan Psikoloji Derneği'nin başkanı olan Martin Seligman tarafından yönetilen pozitif psikoloji, insanlarla olan yanlış şeyleri düzeltmeye çalışmak yerine insanlarla doğru olan şeylerin ne olduğunu inşa etmekle ilgili olan şeylerle ilgilenmiştir. Özellikler, yetenekler, erdemler, mutluluk ve diğerleri gibi birçok olumlu yönelimli güçlü yönleri kapsayan bir teori ve araştırma akışı başlatılmıştır (Luthans ve Youssef, 2004: 151).

Pozitif psikoloji olumlu öznel deneyimle "esenlik ve tatmin (geçmiş); akış, sevinç, duyusal zevkler ve mutluluk (mevcut); ve gelecekle ilgili yapıcı bilişler, iyimserlik, umut ve inanç" ilgilidir. Bireysel düzeyde, kişisel gelişim, sevgi ve meslek, cesaret, kişilerarası beceri, estetik duyarlılık, azim, affetme, özgünlük, gelenek, yüksek yetenek ve bilgelik kapasitesi ile ilgilidir. Grup düzeyinde, bireyleri daha iyi vatandaşlığa sevk eden, yurttaşlık erdemleri ve kurumlarıyla (sorumluluk, güvence, özgecilik, kibarlık, 1lımlılık, hoşgörü ve iş ahlakı) ilgilidir (Gillham ve Seligman, 1999; Seligman ve Csikszentmihalyi, 2000; akt. Seligman, 2002: 3).

Luthans vd. (2007b), organizasyonlarda çalışanların davranışlarını anlama ve değiştirme konusundaki olumlu örgütsel davranış yaklaşımından yola çıkarak, psikolojik sermaye yapısını bir anlayış çerçevesi olarak önermiştir. Psikolojik sermayenin bu yapısı, bireylerin hayatlarındaki engelleri aşmak için kullandığı psikolojik kaynaklar, pozitifin altında yatan temel fikri temsil etmektedir.

\section{Liderlik Davranışları}

Belirli liderlik davranışlarının, çalışanların örgütsel gelişmeyi tetikleme eğiliminde gönüllü olarak yorum veya öneride bulunma kararlarını etkilemede oynadı̆̆ $\breve{1}_{1}$ rol üzerinde odaklanılmıştır (Detert ve Burris, 2007: 869). Çalışan odaklı, üretim odaklı ve değişim odaklı liderlik davranışlarının örgütsel bağlılığa etkisinin pozitif ve anlamlı olduğu tespit edilmiştir (Demiră̆ ve Çelik, 2019: 16).

Literatürde liderlikle ilgili özellikler, davranışsal, durumsal ve modern yaklaşımlar yer almaktadır. Özellikler yaklaşımına göre liderin doğuştan sahip olduğu belirli özellikler değerlendirilmiştir. Davranışsal yaklaşım ile etkin bir liderin göreve çalışana yönelik davranışları göstermesi üzerinde durulmuştur (Bulut ve Meydan, 2018: 225). Değişik koşulların değişik liderlik biçimini gerektirdiği varsayımıyla durumsal liderlik dikkat çekmiştir (Çetin ,2008: 77). Durumsal liderlik kuramları genel olarak her durum ve koşulda geçerli olan belirli bir en iyi liderlik modelinin bulunmadığını, en iyi liderlik tarzının durumsal 
gerekliliklere bağlı olarak değişiklik gösterebileceğini ileri sürmektedir (Başar ve Basım, 2018:127). Modern liderlik kuramları olarak öne çıkanlar arasında; işlemsel liderlik, dönüştürücü liderlik, örtülü liderlik, otantik liderlik ve babacan liderlik sayılabilir (Başar ve Basım, 2018: 131). Transaksiyonel liderlik, liderin izleyicilerini ödüllendirme mekanizmalarını kullanarak etkileyebilmesine dayanmaktadır. Öte yandan, transformasyonel liderlik, ilham verme ve izleyicilerin motivasyonel durumlarının dönüşümünü gerektirmektedir (Gül ve Şahin, 2011: 241).

$\mathrm{Bu}$ çalışmada liderlik davranışları durumsal liderlik kuramı açısından incelenmiştir. Bu yaklaşıma göre her zaman her yerde kabul görebilecek tek bir lider davranış özelliğinin olamayacağı savunulmaktadır. Genel sistem kuramının ortaya çıkmasıyla birlikte çevreyle iletişimi zayıf kapalı sistem örgütler, açık sistem yaklaşımının benimsenmesiyle modern örgüt kuramları gelişmiştir. Açık sistemde örgütler yaşayan bir organizma olarak düşünüldügünnde kendi çevresinden etkilenmektedir. Çeşitli sosyal, yasal, politik, teknik veya ekonomik faktörler düşünüldüğ̈ünde farklı çevresel koşullar farklı örgütsel uygulamaları gerektirmiştir. Bu gereklilik durumsallık yaklaşımını geliştirmiştir (Çetin ve Şeşen, 2015). Bu çalışmanın yer aldığ1 sanayi bölgesindeki örgütün de çevresinden etkilendiği ve örgütte oluşan alt sistemlerdeki hiyerarşide farklı liderlik davranışlarının ortaya çıkabileceği varsayılmıştır.

Organizasyonları değişim doğrultusunda yönlendirmek yöneticilerin görevleri arasında yer almıştır. Değişim odaklı davranışı işaret eden dönüşümcü (transformasyonel) ve karizmatik liderlik teorileri bu bağlamda ortaya çıkmıştır. Yukl (2012) tarafından değişim odaklı liderlik boyutunu, Michigan Üniversitesi çalışmalarında öne sürülen görev odaklı ve ilişki odaklı liderlik davranışı boyutlarına ekleyerek üç boyutlu bir liderlik davranış modeli önerilmiştir (Özşahin ve Zehir, 2011: 50; Ağca ve Döven, 2016: 847).

Liderlik davranışı ile ilgili yapılan ilk araştırmaların çoğunda odaklanılan liderlerin iş ünitesindeki astları ve iç faaliyetleri nasıl etkilediği açıklanmaktadır. Yukl (2012), makalesinde bir ekibin, iş biriminin veya organizasyonun performansını etkilemede görev, ilişki ve değişim odaklı liderlik davranışlarını açıklamaktadır (Yukl, 2012: 68).

Ekvall ve Arvonen (1991) çalışmasında liderlik davranışları değişim odaklı, ilişki odaklı ve görev odaklı tarzlar olmak üzere üç boyutta ele alınmıştır. Değişim odaklı liderlik, değişen çevresel şartları anlamaya ve uyum sağlamak üzere örgütün stratejisinde, üretim ile hizmetlerinde ve işleyen süreçlerinde büyük değişimlerin yapılmasıyla ilgili davranıştır. "Dönüşümsel liderlik", "değişim odaklı liderlik" tarzına benzer; her ikisi de yeni yönlere, hedeflere ve genellikle vizyonlara sahip olma durumunu ifade etmektedir. Fakat "dönüşümcü" lider, Maslowian ihtiyaç hiyerarşisinde astları üst seviyelere çeken karizmatik ve ilham verici bir figür iken, analizde ortaya çıkan değişim merkezli liderlik tarzı işin ve organizasyonun gelişimine daha fazla odaklanmış gibi görünmektedir. Değişim merkezli yeni liderlik davranış boyutu, iş dünyasında ve çalışma hayatında bir gerçek gibi göründüğü ifade edilmiştir (Ekvall ve Arvonen, 1991: 23).

Üretim/görev odaklı liderlik davranışı, önceliğin görevin etkin bir şekilde yapılması için beşeri ve maddi kaynakların etkin bir şekilde kullanılması ve faaliyetlerin güvenli ve düzenli bir şekilde gerçekleştirilmesinin sağlanmasına yönelik davranış boyutu; ilişki/çalışan odaklı liderlik, çalışanlarla ilişkilerin yüksek düzeyde tutulmasına öncelik verilmesi, astlara işlerinde yardım edilmesine, organizasyonla bütünleşmenin sağlanmasına ve çalışanların gelişimine yönelik davranışlar olduğu açıklanmıştır (Yukl, 2010: 58; aktaran Özşahin ve Zehir, 2011: 50; 
Ekvall ve Arvonen, 1991: 23). Üç farklı davranış boyutunu bir araya getirebilen yeni bir teori ve liderlik stiller modelinin gerekli olduğu ifade edilmiştir. Modelin ana alanları değişim, üretim merkezli ve ilişki merkezli liderlik olmalıdır. (Şekil 2) (Ekvall ve Arvonen, 1991: 24).

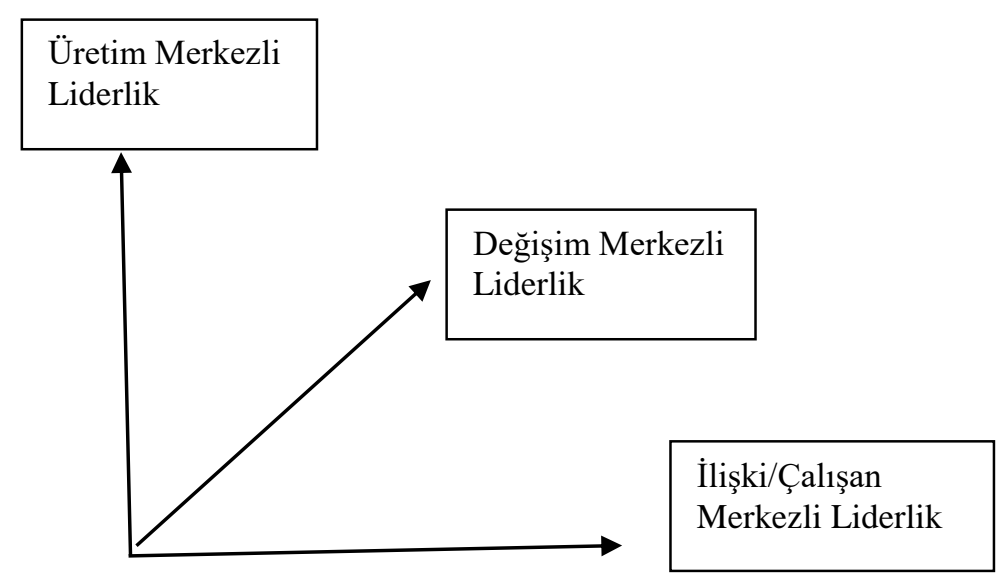

Şekil 2. Ekvall ve Arvonen (1991) Liderlik Modelleri

Ekvall ve Arvonen (1991: 25) çalışmasında liderlik davranış biçimlerinde, düşük ilişki odaklılık ve düşük değişim merkezli olma ile yüksek üretim merkezli bir modelden uzak olmuştur. Daha yüksek çalışan odaklılık ve daha yüksek değişim odaklılık ile daha düşük üretim merkezli olma yolunda farklılık gözlenmiştir.

\section{Liderlik Davranışları ve Psikolojik Sermaye İlişkisi}

Bulgular, amirlerin dönüşümsel liderlik dereceleri ile psikolojik sermaye arasındaki çalışan puanları arasında güçlü pozitif ilişkiler olduğunu göstermektedir (McMurray vd., 2010). Dönüşüm lideri için yüksek seviyede algı düzeyine sahip çalışanların çoğunun psikolojik açıdan, umut, iyimserlik, esneklik ve etkinlik bakımından emsallerinden daha güçlü olduğu (Ismail vd., 2011); takipçiler tarafından algılanan hizmetçi liderlik ile takipçilerin psikolojik sermaye algısı arasında pozitif bir ilişki olduğu (Coggins ve Bocarnea, 2015); psikolojik sermaye unsurlarının otantik liderlik unsurlarının yordayıcısı olduğu (Keser ve Kocabaş, 2014); dönüşümsel ve etkileşimsel liderlik davranışlarının çalışanların psikolojik sermayesini olumlu yönde yordadığı (Li vd., 2018); psikolojik sermayenin, koçluk liderliği ve çalışanın sesli davranışı(bir kuruluşun verimliliğini artırmak için bir üst yöneticiye gönüllü olarak yapıcı fikirler sunan bir çalışan davranışı) arasındaki ilişkiye aracılık etkisinin olduğu (Wang vd., 2017); kapsayıcı liderliğin, çalışanın psikolojik sermayelerini artırarak inovasyon performansını dolaylı olarak iyileştirebileceği (Xiang vd., 2017) sonuçları elde edilmiştir.

İnsan kaynağına yatırım ve kaynağı geliştirmenin yanı sıra, psikolojik sermayenin liderlerin takipçilerini nasıl etkilediğine odaklanan araştırmalar vardır. Örneğin, Avolio ve Luthans (2006), daha özgün ve dönüştürücü olan liderlerin, takipçilerinin motivasyon eğilimleri üzerinde daha olumlu bir etkiye sahip olacağını ileri sürmüşlerdir (Luthans vd., 2007a: 568). 
Bir liderin pozitif olma seviyesi aynı zamanda takipçilerin düşüncelerini, hislerini ve davranışlarını etkilemektedir. Etkili liderliğin örgütün genelinde pozitif (ilham, motivasyon, güven) yayılması gerektiği kabul edilmektedir. Psikolojik sermayesi yüksek liderler bunu duygusal bulaşma süreci boyunca yapabilir ya da Daniel Goleman ve meslektaşlarının "İlkel Liderlik" kitabındaki duygusal rezonans dediği şeyleri yapabilirler. Olumlu bir liderin yanında olan takipçiler liderin duygularını yakalayabilir (Peterson, Balthazard, Waldman ve Thatcher, 2008: 345).

Psikolojik sermaye geliştirilebileceğinden (Luthans vd., 2006), çalışanların psikolojik sermayesine yatırım yapmak ve geliştirmek, organizasyonlar ve liderleri için çeşitlendirilmiş işgücü ortamına meydan okumak için önemli olabileceği ifade edilmektedir. Avolio ve Luthans (2006), daha özgün ve dönüştürücü olan liderlerin, takipçilerinin motivasyon eğilimleri üzerinde daha olumlu bir etkiye sahip olacağını ileri sürmüşlerdir (Tüzün, Çetin ve Basım, 2014: 98).

Otantik liderlik, psikolojik sermayeyi artırma ve psikolojik iklimi iyileştirme açısından kritik olan pozitif örgütsel davranışın çekirdeğini oluşturmaktadır. Daha yüksek bir öz-farkındalık, içselleştirilmiş bir ahlaki bakış açısı, bilginin dengeli bir şekilde işlenmesi ve çalışanlarla liderleri arasındaki ilişkisel şeffaflığın teşvik edilmesi için hem pozitif psikolojik kapasiteleri hem de olumlu bir etik iklimi kendine çeken ve destekleyen hem liderlerin hem de astlarının kendi gelişimlerini takip eden ve geliştiren bir lider davranış modeli olarak kabul edilmektedir. (Walumbwa, Avolio, Gardner, Wernsing ve Peterson, 2008: 94; Munyaka vd., 2017: 2)

Bulgular otantik liderlerin, çalışanların yaratıcılığının önemli bir yordayıcısı olduğunu ve ilişkinin işlediği süreçleri anlamaya yardımcı olduğunu ileri sürmektedir. Çalışanlar daha yüksek psikolojik sermaye geliştirdiğinden otantik liderler çalışanların yaratıcılığını arttırır (Rego, Sousa, Marques ve Cunha, 2012: 435). Otantik liderlik, psikolojik sermaye boyutları ve çalışan performansı arasında anlamlı pozitif yönde bir ilişki olduğu açıklanmaktadır. (Taşliyan ve Hırlak, 2016: 92).

Arizona Devlet ve Syracuse Üniversitesi'nden araştırmacılar, umut verici ve iyimser CEO'ların daha etkin kuruluşlara sahip olduklarını ifade etmiştir (Peterson, Balthazard ve Waldman, 2008: 344). Yönetim tarafından kariyer imkanlarının geliştirilmesi, başarıya prim verilmesi, çeşitli özel etkinlikler düzenlenmesi gibi katkıların sağlanmasıyla çalışanların psikolojik sermayelerinin geliştirilmesi gerekmektedir. Yetgin, (2016) araştırma sonucuna göre, bilgi, deneyim ve yeteneğine inanan, kendine güvenen, zorluklarla başa çıabilen öz yeterliliğe sahip bir bireyin algısı, otantik liderlik tarzını desteklemektedir (Yetgin, 2016: 148).

Kızrak, Bıçakçı ve Basım (2017), çalışmasından elde edilen bulgulara göre farklı öz-liderlik davranışları, farklı psikolojik sermaye faktörlerinden etkilenmektedir. Özellikle de umut ve iyimserlik düzeylerinin arttırılması, çalışanların öz-liderlik, öz-disiplin ve kendi kendini motive etme ve yönetebilme becerilerinin gelişmesinde önemli bir unsur olarak değerlendirilmektedir (Kızrak, Bıçakçı ve Basım 2017: 810).

Gyu Park vd, (2017) araştırma sonuçlarında, güçlendirici liderliğin çalışanların psikolojik sermayesi üzerinde önemli bir etkisi olduğunu ve çalışanların iş ilişkisini doğrudan etkilediğini belirtmiştir. Liderlerin güçlendirici davranışlarının, çalışanların kişisel çalışmalarına ve hayatlarına karşı zihinlerini olumlu yönde etkilediği ifade edilmiştir. Bu araştırma liderliğin, işyerinde güçlenmeyle birlikte, çalışanların psikolojik sermayesini 
artırarak çalışanların pozitif iyilik halinin ve iş ilişkisinin artmasına katkıda bulunabileceğini göstermektedir (Gyu Park, Sik Kim, Yoon ve Joo 2017: 360).

Araştırmalar, liderlerin umudunun iş birimi finansal performansı, çalışanların iş tatmini ve işte tutulmaları üzerinde önemli ve pozitif bir etkiye sahip olduğunu göstermiştir. Kültürler arası bir çalışmada, devlete ait bir işletmede Çinli işçilerin umudunun performanslarıyla ilgili olduğu bulgulanmıştır (Luthans ve Youssef, 2004: 153).

Luthans ve Youssef (2004: 158), özellikle olumlu psikolojik sermaye yönetiminin, insanların yeteneklerini, güçlerini ve psikolojik kapasitelerini değerli, üretken, etik ve sürdürülebilir sonuçlar elde etmeye doğru etkili bir şekilde kanalize edebileceğini ve rekabet avantaj1 sağlayacağını önermektedir.

\section{Literatürde yer alan araştırma sonuçları kapsamında aşağıda belirtilen hipotez oluşturulmuştur:}

$\mathrm{H}_{1}$ : Yöneticilerin liderlik davranışlarının çalışanların pozitif psikolojik sermaye düzeyleri üzerinde etkisi vardır.

\section{Araştırmanın Yöntemi}

\section{Araştırmanın Modeli}

Alanyazında açıklanan ilişkilerden hareketle, bu araştırmada liderlik davranışlarının psikolojik sermaye üzerine etkisi araştırılmıştır. Araştırma kapsamındaki değişkenlerin katılımcıların demografik özelliklerine göre farklılaşma durumuna bakılmıştır. Geliştirilen araştırma modeli Şekil 3'te gösterilmiştir.

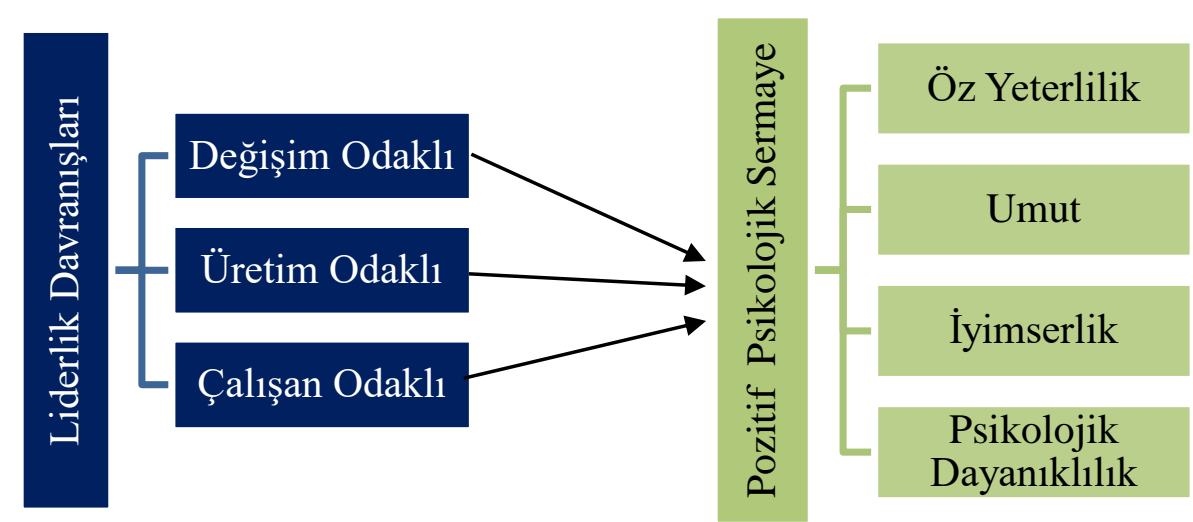

Şekil 3. Araştırma Modeli

\section{Araştırmanın Evren ve Örneklemi}

Araştırmanın evrenini Gaziantep ilinde 2. Organize sanayi bölgesindeki çalışanlar oluşturmaktadır. İşletmelerin tümüne ulaşmada birtakım zorluklar olmasından dolayı, araştırmada belirlenen evren üzerinden örneklem alınmıştır. Olasılık dışı örnekleme yöntemlerinden kolay örnekleme yöntemiyle örneklem seçilmiştir. 2018 yılında bölgede 270 
firma ve 5000'e yakın çalışan bulunmaktadır. Anket formu Organize Bölge Müdürlüğü aracılığıyla çalışanlara e-posta ile gönderilmiştir. 167 çalışan anketi yanıtlamıştır. Boş bırakılan anket soruları nedeniyle 161 anketten toplanan veriler değerlendirilmiştir. Örneklem büyüklüğü mevcut ana kütleyi \%90 güven aralığında temsil yeteneğine sahiptir.

\section{Veri Toplama Araçları}

\section{Psikolojik Sermaye Ölçeği}

Luthans vd., (2007a) tarafından geliştirilen ve Türkçe'ye Basım ve Çetin (2012) tarafından uyarlanan 6'lı Likert ölçeği 24 maddeden; “öz yeterlilik", "psikolojik dayanıklılık”, "umut” ve "iyimserlik" alt boyutlarından oluşmaktadır.

Araştırmada kullanılan psikolojik sermaye ölçeğinin yapı geçerliliğini tespit etmek için yapılan KFA sonucunda, Kaiser-Meyer- Olkin (KMO) örneklem yeterlilik değeri 0,878 bulunmuştur. KFA neticesinde dört faktör ortaya çıkmıştır. Bu dört faktörlü yapı, faktörlerin toplam varyansı $\% 58,262$ oranında açıkladığı tespit edilmiştir.

\section{Liderlik Özellikleri Ölçeği}

Ekvall ve Arvonen (1991) tarafından geliştirilmiştir. İsveç, Finlandiya ve ABD'deki personel eğitim merkezlerinde kurs alan kişilerden alınan üç grupta, liderlik davranışı anketinin faktör analizi aynı liderlik stillerini ortaya koymuştur. Tüm katılımcılar 36 maddelik bir ankette kendi yöneticilerini tanımlamışlardır. Her örneklem grubunda çalışan/ilişki merkezli olma, üretim merkezli olma ve değişim merkezli liderlik davranışları olmak üzere üç güçlü faktör ortaya çıkmıştır (Ekvall ve Arvonen, 1991: 17).

Verilerin toplanmasında kullanılan anket formundaki liderlik davranışlarına ilişkin Ekvall ve Arvonen (1991) tarafından geliştirilen liderlik davranış ölçeği kullanılmıştır. 36 ifadeden oluşan bu ölçek Tengilimoğlu (2005) çalışmasında Türkçe uyarlaması yapılmıştır. Ekvall ve Arvonen (1991), ölçeğin iç tutarlılık değerini (0,88); Tengilimoğlu (2005: 232), iç tutarlılık değerini $(0,97)$ olarak bulmuşlardır.

Araştırmada kullanılan liderlik özellikleri ölçeğinin yapı geçerliliğini tespit etmek amacıyla keşfedici faktör analizi (KFA) uygulanmıştır. KFA sonucunda, KMO örneklem yeterlilik değerinin 0,939 ve örneklem büyüklüğü faktör analizi için yeterlidir. Bartlett testinin anlamlı olması $\left(\chi^{2}(465)=3560,875 ; p<0,001\right)$ maddeler arasındaki korelasyon ilişkilerinin faktör analizi için uygun olduğunu göstermektedir. KFA neticesinde üç faktör ortaya çıkmıştır. Bu üç faktörlü yapı, faktörlerin toplam varyansı \%60,112 oranında açıkladığı tespit edilmiştir. Ölçeğin 5 maddesi $(5,8,11,15,23)$ açıklanan varyansa katkısının düşük olmasından ve çapraz yüklenme eğilimi göstermesinden dolayı ölçekten çıkarılmıştır.

\section{Ölçek Geçerlilik ve Güvenilirlik Analizleri}

Liderlik davranışları ölçeğinin üç boyutlu yapısı ile psikolojik sermaye ölçeğinin dört boyutlu yapısını doğrulamak için AMOS İstatistik Programı ile Doğrulayıcı Faktör Analizi/DFA 
yapılmıştır. DFA yapılırken ikinci seviye çok faktörlü model test edilmiştir. DFA sonuçları Tablo 1'de gösterilmiştir.

Tablo 1. Doğrulayıcı Faktör Analizi Sonuçları

\begin{tabular}{l|c|c|c|c}
\hline Ölçek & $\chi \mathbf{2} / \mathbf{s d}$ & RMSEA & CFI & IFI \\
\hline Kriter & $\leq 5$ & $\leq 8$ & $>\mathbf{0 , 9 0}$ & $>\mathbf{0 , 9 0}$ \\
Psikolojik Sermaye & 1,63 & 0,06 & 0,91 & 0,91 \\
Liderlik Davranışları & 1,87 & 0,07 & 0,90 & 0,90 \\
\hline
\end{tabular}

Ölçek istatistiksel olarak anlamlıdır. Liderlik davranışları ölçeği (üç faktörlü model) ve psikolojik sermaye ölçeği (dört faktörlü model) uyum iyiliği değerleri kabul edilebilir sınırlar içerisinde yer almaktadır. Ölçeklerin yapısının istatistiksel olarak geçerli olduğu tespit edilmiştir.

Luthans vd., (2007a) geliştirmiş olduğu ölçeğin geçerliliği için iki örneklem grubunda DFA yapılmıştır. İki örneklem grubunda da en iyi uyum değerlerinin dört boyutlu yapıya ait olduğu tespit edilmiştir. Birinci örneklem gurubunda $X^{2}=422.7 ; \mathrm{df}=234 ; \mathrm{RMSEA}=0,046$; $\mathrm{CFI}=0,93$ ve ikinci örneklem grubunda $\mathrm{X}^{2}=448.2 ; \mathrm{df}=234 ; \mathrm{RMSEA}=0,048 ; \mathrm{CFI}=0,924$ sonuçlarıyla iyi uyum değerlerine sahiptir (Luthans vd., 2007a: 559; Çetin ve Basım, 2012: 128).

Tablo 2. Ölçek Güvenilirlik Analiz Sonuçları

\begin{tabular}{lccc}
\hline \multicolumn{1}{c}{ Ölçek Adı } & Cronbach's Alpha & $\begin{array}{c}\text { Cronbach's Alpha Based } \\
\text { on Standardized Items }\end{array}$ & N of Items \\
\hline Liderlik Davranışları Genel &, 963 &, 963 & 30 \\
Çalışan Odaklı Lider Dav. &, 931 &, 932 & 12 \\
Değişim Odaklı Lid. Dav. &, 902 &, 902 & 9 \\
Üretim Odaklı Lid. Dav. &, 908 &, 908 & 9 \\
\hline Psikolojik Sermaye Genel &, 877 &, 901 & 24 \\
İyimserlik &, 653 &, 666 & 6 \\
Dayanıklılık &, 614 &, 656 & 6 \\
Umut &, 777 &, 787 & 6 \\
Öz yeterlilik &, 840 &, 840 & 6 \\
\hline
\end{tabular}

30 maddeden oluşan Liderlik Davranışları ölçeğinin Cronbach alfa güvenilirlik katsayısı 0,963'tür. Bu değer ölçeği oluşturan maddelerin iç tutarlılık güvenilirliğini göstermektedir. Ölçeğin çalışan odaklı liderlik alt boyutu 0,932; değişim odaklı liderlik alt boyutu 0,902; üretim odaklı liderlik alt boyutu 0,908 güvenilirlik katsayısı tespit edilmiştir. 
24 maddeden oluşan Psikolojik Sermaye ölçeğinin, Cronbach alfa güvenilirlik katsayısı 0,901'dir. Ölçekteki maddeler arasında içi tutarlılık değeri yüksektir ve kabul edilebilir düzeydedir. Ölçeğin alt boyutları olan iyimserlik 0,666; dayanıklılık 0,656; umut 0,787; öz yeterlilik 0,840 güvenilirlik katsayısına sahiptir.

\section{Bulgular}

\section{Tanımlayıcı İstatistikler}

Tanımlayıcı istatistiklere ilişkin bulgular Tablo 3’te verilmiştir.

Tablo 3.Tanımlayıcı Bulgular

\begin{tabular}{|c|c|c|c|c|c|}
\hline Yaş & $\mathbf{N}$ & $\%$ & Çalışma Yılı & $\mathbf{N}$ & $\%$ \\
\hline $20-25$ & 43 & 26,7 & $0-1$ yıl & 26 & 16,1 \\
\hline $26-30$ & 43 & 26,7 & 2-5 y1l & 60 & 37,3 \\
\hline $31-35$ & 38 & 23,6 & 6-10 yıl & 48 & 29,8 \\
\hline $36-40$ & 21 & 13,0 & $11-15$ yil & 12 & 7,5 \\
\hline 41 ve üzeri & 11 & 6,8 & 16 yıl ve üzeri & 7 & 4,3 \\
\hline Cevapsiz & 5 & 3,1 & Cevapsız & 8 & 5,0 \\
\hline Toplam & 161 & 100,0 & Toplam & 161 & 100,0 \\
\hline Cinsiyet & $\mathbf{N}$ & $\%$ & Medeni Durum & $\mathbf{N}$ & $\%$ \\
\hline Kadın & 63 & 39,1 & Evli & 86 & 53,4 \\
\hline Erkek & 90 & 55,9 & Bekar & 69 & 42,9 \\
\hline Cevapsiz & 8 & 5,0 & Cevapsiz & 6 & 3,7 \\
\hline Toplam & 161 & 100,0 & Toplam & 161 & 100,0 \\
\hline Eğitim Durumu & $\mathbf{N}$ & $\%$ & & & \\
\hline İlköğretim & 7 & 4,3 & & & \\
\hline Lise & 32 & 19,9 & & & \\
\hline Ön Lisans & 45 & 28,0 & & & \\
\hline Lisans & 61 & 37,9 & & & \\
\hline Lisansüstü & 11 & 6,8 & & & \\
\hline Cevapsiz & 5 & 3,1 & & & \\
\hline Toplam & 161 & 100,0 & & & \\
\hline
\end{tabular}

Araştırma grubunda yer alan çalışanların \%53,4'ü 30 yaşın altında, \%55,9'u erkek, \%52,2'si ön lisans ve altı eğitim seviyesinde, \%83,2'si işyerinde 10 yıldır çalışmakta ve \%53,4'ü evlidir.

Araştırma değişkenlerine ilişkin istatistikler incelendiğinde, liderlik davranışlarının tüm boyutlara ait puanlarının ortalamanın üzerinde olduğu ve üretim (görev) odaklı liderlik $($ Ort. $=4,14$, S.s. $=0,70)$, çalışan/ilişki odaklı liderlik (Ort.= 3,90, S.s. $=0,77)$ ve değişim odaklı liderlik boyutlarının (Ort. $=4,02$, S.s. $=0,72$ ) ortalamanın üzerinde değerdedir. Psikolojik sermayeye ilişkin istatistikler incelendiğinde, ortalamanın (Ort. $=4,40$, S.s. $=0,52$ ) üzerinde olduğu saptanmıştır. Araştırma değişkenlerine ilişkin istatistikler Tablo 4'te gösterilmiştir. 
Tablo 4. Değişkenlere Ait İstatistikler

\begin{tabular}{llccc}
\hline & & N & Ort. & S.s. \\
\hline Liderlik Davranışları Çalışan/İlişki Odaklı & 161 & 3,9084 &, 77634 \\
& Değişim Odaklı & 161 & 4,0242 &, 72475 \\
& Üretim Odaklı & 161 & 4,1463 &, 70212 \\
\hline Psikolojik Sermaye & İyimserlik & 161 & 4,1858 &, 54608 \\
& Dayanıklılık & 161 & 4,3023 &, 63573 \\
& Umut & 161 & 4,4948 &, 65310 \\
& Öz yeterlilik & 161 & 4,6335 &, 521369 \\
& PS Genel Ortalama & 161 & 4,4040 &, 52132 \\
\hline
\end{tabular}

Yöneticilerin liderlik davranışlarında ilk sırada üretim odaklı olan idarecilerin olduğu göze çarpmaktadır. İkinci sırada değişim odaklı liderlik davranışları yer almaktadır. Çalışan (ilişki) odaklı liderlik tarzına ait puan ortalaması en düşük puana sahiptir.

Çalışanların psikolojik sermaye seviyelerinin yüksek olduğu söylenebilir. Psikolojik sermaye boyutlarına bakıldığında en yüksek ortalama öz yeterlilik düzeyinde olduğu görülmektedir. İkinci sırada umut, üçüncü sırada dayanıklılık, son sırada iyimserlik yer almaktadır.

\section{Korelasyon Analizi}

Liderlik tarzları ve alt boyutları ile psikolojik sermaye ve alt boyutları değişkenleri arasındaki ilişkinin tespiti korelasyon analiziyle yapılmıştır. Korelasyon analizine ait sonuçlar Tablo 5 'te sunulmuştur.

Tablo 5. Değişkenler Arasındaki Korelasyon Analizi

\begin{tabular}{|c|c|c|c|c|c|c|c|}
\hline Değişken & 1 & 2 & 3 & 4 & 5 & 6 & 7 \\
\hline Çalışan/İlişki & 1 & & & & & & \\
\hline Değişim &, $772^{* *}$ & 1 & & & & & \\
\hline Üretim &, $776^{* *}$ &, $770^{* *}$ & 1 & & & & \\
\hline İyimserlik & $285^{* * *}$ &, $257^{* *}$ &, $307^{* *}$ & 1 & & & \\
\hline Dayanıklılık & $267^{* * *}$ &, $268^{* *}$ &, $297^{* *}$ &, $486^{* *}$ & 1 & & \\
\hline Umut & $434^{* * *}$ &, $347^{* *}$ &, $416^{* *}$ &, $559^{* * *}$ & $674^{* *}$ & 1 & \\
\hline Öz yeterlilik &, $374^{* *}$ & ,291** &, $401^{* *}$ & $481^{* *}$ & $696^{* * *}$ & ,760** & 1 \\
\hline
\end{tabular}

** $\mathrm{p}<.01$

Bağımsız değişkenler arasındaki korelasyon katsayıları incelendiğinde pozitif yönlü ilişkiler görülmektedir. Yöneticilerin değişim, ilişki ve görev odaklı liderlik davranışları ile çalışanların psikolojik sermayeyi oluşturan iyimserlik, dayanıklılık, umut ve öz yeterlilik düzeyleri arasında doğrusal bir ilişki olduğu bulgulanmıştır. 


\section{Regresyon Analizi}

Araştırma hipotezi kapsamında liderlik davranışlarının psikolojik sermaye üzerindeki etkisini ölçmek üzere basit doğrusal regresyon analizi yapılmıştır.

Tablo 6. Liderlik Davranışının Psikoloji Sermayeye Etkisi Regresyon Analizi

\begin{tabular}{lcccc}
\hline Model & $\mathbf{R}$ & $\mathbf{R}^{2}$ & Düzeltilmiş $\mathbf{R}^{2}$ & $\begin{array}{c}\text { Tahminin Standart } \\
\text { Hatası }\end{array}$ \\
\hline 1 & $441^{\text {a }}$ &, 194 &, 179 &, 47238 \\
\hline
\end{tabular}

a. Predictors: (Constant), LD_Üretim, LD_Değişim, LD_Çalışan

Değişkenler arası çoklu ilişkiyi gösteren $R$ değerinin 0,441 olduğu görülmektedir. $R^{2}$ değeri ( $R$ Square), bağımlı değişkendeki (psikolojik sermaye) değişimlerin ne kadarının bağımsız değişkenler (çalısan/ilişki, değisim, üretim) tarafından açıklandığını gösterir. Buna göre psikolojik sermaye düzeyindeki \%19'luk değişimin liderlik davranışları bağımsız değişkenlerine bağlı olduğu söylenebilir. Düzeltilmiş $\mathrm{R}^{2}$ değerine göre; psikolojik sermaye düzeyindeki \%18'lik varyansın bağımsız değişkenlere bağlı olduğu söylenebilir.

Tablo 7. Regresyon Modelinin Anlamlılık Sonuçları

\begin{tabular}{|c|c|c|c|c|c|c|c|}
\hline \multirow[b]{2}{*}{ Model } & \multicolumn{2}{|c|}{$\begin{array}{c}\text { Standartlaştırılmamış } \\
\text { Katsayılar }\end{array}$} & \multirow{2}{*}{$\begin{array}{c}\begin{array}{c}\text { Standartlaştırılmış } \\
\text { Katsayılar }\end{array} \\
\text { Beta }\end{array}$} & \multirow[b]{2}{*}{$t$} & \multirow[b]{2}{*}{ Sig. } & \multirow[b]{2}{*}{ F } & \multirow[b]{2}{*}{ Sig. } \\
\hline & B & Std. Hata & & & & & \\
\hline 1 (Constant) & 3,068 & 231 & & 13,266 & ,000 & 12,622 &, $000^{\mathrm{b}}$ \\
\hline İlişki/Calısan & 136 & 085 & ,202 & 1,602 & ,111 & & \\
\hline Degisim &,- 024 & ,090 &,- 033 &,- 268 & ,789 & & \\
\hline Uretim & ,218 & ,093 & 293 & 2,333 & 021 & & \\
\hline
\end{tabular}

Regresyon modeli istatistiksel olarak anlamlı bulunmuştur. Düzeltilmiş $\mathrm{R}^{2}$ değerine göre; psikolojik sermaye düzeyindeki \%18'lik varyansın üretim, değisim, çalışan/ilişki odaklı liderlik davranışı bağımsız değişkenler tarafından açılandığını gösterir. Tablodaki Beta katsayıları incelendiğinde, tüm bağımsız değişkenler regresyon modeline sokulduğu zaman psikolojik sermaye düzeyini açıklamada sadece üretim odaklı liderlik davranışlarının anlamlı katkısı olduğu tespit edilmiştir $(\beta=0,21, \mathrm{p}<0.01)$. 
Tablo 8. Liderlik Davranışının Psikoloji Sermayeye Alt Boyutlarına Etkisi Regresyon Analizi

\begin{tabular}{lccccc}
\hline Model & $\mathbf{R}$ & $\mathbf{R}^{2}$ & Düzeltilmiş $\mathbf{R}^{2}$ & $\begin{array}{c}\text { Tahminin } \\
\text { Standart Hatası }\end{array}$ & $\mathbf{p}$ \\
\hline 1̇́yimserlik &, 316 &, 100 &, 083 &, 52302 &, 001 (yok) \\
\hline 2Dayanıklılık &, 305 &, 093 &, 076 &, 61117 &, 002 (yok) \\
\hline 3Umut &, 453 &, 206 &, 190 &, 58767 &, 000 (Çalışan) \\
\hline 4Özyeterlilik &, 421 &, 177 &, 161 &, 58491 &, 000 (Üretim)
\end{tabular}

a. Predictors: (Constant), LD_Üretim, LD_Değişim, LD_Çalışan

Liderlik davranışlarının psikolojik sermayenin alt boyutları üzerindeki etkisi incelendiğinde; çalışan odaklı liderlik davranışının umut boyutu, üretim odaklı liderlik davranışının öz yeterlilik boyutu üzerinde anlamlı etkisi olduğu tespit edilmiştir. Ancak umut, iyimserlik, öz yeterlilik ve psikolojik dayanıklılık alt boyutları, birbirlerinden bağımsız ve ayrışma geçerliliği olmakla birlikte; tek bir teorik ve ölçülebilir bir yapı olarak örgütsel psikolojik sermayeyi açıklamaktadır (Luthans vd., 2007a; Çetin ve Basım, 2012). Bütün parçalardan daha önemli görülmüş olup psikolojik sermayenin tek yapıda değerlendirilmesi uygun görülmüştür.

\section{Demografik Değişkenler Açısından Değişkenlerin İncelenmesi}

Demografikler değişkenler açısından yapılan testlerde anlamlı bulgunun yalnızca Medeni durum değişkeni açısından anlamlı farklılaşma tespit edilmiştir. Evli olan çalışanların psikolojik sermaye düzeylerinin bekar olan çalışanlara göre daha yüksek olduğu tespit edilmiştir.

\section{Sonuç ve Değerlendirme}

Bono ve Ilies (2006), liderlerin olumlu duygusal ifadelerinin, takip edenlerin ruh halleri ile pozitif ilişkili olduğunu ve lider davranışının, izleyicinin algıladığı psikolojik kaynakları etkileyebilecek göze çarpan bir bilgi kaynağı olduğu sonucuna varmışlardır (Bono ve Ilies, 2006: 330; Walumbwa, Peterson, Avolio ve Hartnell, 2010: 941).

$\mathrm{Bu}$ çalışma, liderlik davranışlarının çalışanın psikolojik sermayeleri üzerindeki etkisini araştırmak amacıyla yapılmıştır. Araştırmanın değişkenleri kapsamında psikolojik sermaye puanının ortalamanın üzerinde olduğu tespit edilmiştir. Çalışanların psikolojik sermaye seviyeleri yüksektir. Psikolojik sermaye düzeylerine bakıldığında en yüksek seviyenin öz yeterlilik boyutunda olduğu görülmektedir. Xu vd., (2017) 3,57; Gyu Park vd. (2017) 4,52; Yetgin (2016) psikolojik sermaye alt boyutlarının hepsinde 4,00 ortalamanın üzerinde; Tüzün vd. (2014) çalışmalarında da psikolojik sermaye düzeylerinde ortalamalar $(4,62)$ yüksektir ve bu çalışma ile paralellik göstermektedir.

Çalışanların liderlik davranışları algılarına ait ortalamalar incelendiğinde üretim odaklı liderliğin en yüksek ortalamaya sahip olduğu sonucuna ulaşılmıştır $(X=4,14)$. Yöneticiler; üretim, değişim, çalışan/ilişki odaklı liderlik davranışlarından üretim odaklı davranışları daha 
fazla göstermektedir. Üretim odaklı liderlik davranışlarını yüksek düzeyde gösteren yöneticiler, çalışanlara zorlu görevlerde başarılı olmak için gerekli çabayı sürdürecek güveni kazanmalarını sağlayabilir. Bu sonuç Ekvall, ve Arvonen (1991) araştırma sonucuna göre daha yüksek çalışan/ilişki odaklılık ve daha yüksek değişim odaklılık ile daha düşük üretim merkezli olma yolunda (Ekvall ve Arvonen, 1991: 25) farklılık gözlenmiştir.

Bulut ve Meydan (2018), araştırmasında çalışanların liderlik tarzlarına yönelik algılarına göre, en yüksek ortalamanın (Ort.=3,73) görev odaklı liderliğe ait olduğu ifade edilmiştir. (Bulut ve Meydan 2018: 238). Mevcut çalışmanın sonuçları bu araştırmayı destekler niteliktedir.

Araştırmanın değişkenleri açısından bakıldığında liderlik davranışlarının çalışanların psikolojik sermaye düzeyleri üzerinde etkisi vardır. Bu sonuca göre geliştirilen $\mathrm{H}_{1}$ hipotezi desteklenmiştir. Üretim odaklı liderlik davranışlarının çalışanların psikolojik sermayeleri üzerinde etkisi vardır. Sanayi bölgesindeki işletmelerdeki yöneticilerin işletme çıtılarına daha fazla odaklanmasıyla üretim odaklı davranışları daha fazla gösterdiği düşünülebilir. Ekvall ve Arvonen (1991) liderlik davranışları araştırmasında değişim odaklı liderlik davranışlarının önemi vurgulanmıştır. Bu araştırmada üretim odaklı liderlik davranışları gösteren yönetici takipçilerinin psikolojik sermayelerinin yüksek olması araştırmanın özgün sonucunu ortaya koymaktadır. Üretim odaklı ya da daha genel ifade ile işe yönelik liderlik, iş planlarını çok dikkatli yaparlar, çalışanların sorumluluklarını bilir ve ona göre talimatları açık bir şekilde verir, işin denetimini titizlikle gerçekleştirir. Bu davranışları incelediğimizde karşımıza yönetim süreci çıkmaktadır. Bu süreç bilimsel yönetim yaklaşımının yer aldığı dönemden beri planlama, örgütleme, yöneltme, koordinasyon ve denetim fonksiyonlarından oluşmaktadır. Üretim odaklı davranış gösteren liderlerin yönetim sürecini tam anlamıyla gerçekleştirdiği varsayılabilir. Kuralcı ve iş süreçlerinde titiz olunan bir iş alanında çalışanın zorlu işlerin üstesinden gelmek için çabalaması, hedeflere ulaşmada üretim odaklı olması psikolojik sermaye açısından özyeterlilik düzeyini, belirsizlik yaşandığında çalışanda alternatif yollar üretme arzusu umut düzeyini; denetim aşamasının aktif olması başarının tekrar tekrar elde edilebileceği inancıyla iyimserlik ve dayanıklılık kapasitesini geliştirecektir. Burada yöneticinin iş yönetim sürecine güven duygusunun gelişmesi de söz konusudur denilebilir.

Araştırma tanımlayıcı değişkenler açısından incelendiğinden sadece medeni durum değişkeni açısından anlamlı farklılaşma bulgulanmıştır. Evli olanların psikolojik sermayesinin, bekar olanlara göre daha yüksek olduğu tespit edilmiştir. Bu durum evli olanların hayatlarında almış oldukları sorumlulukların ve yönetmek zorunda oldukları aile ilişkilerinin onların psikoloji kaynaklarını güçlendirerek psikolojik sermaye düzeylerini olumlu yönde etkilediği söylenebilir. 


\section{Kaynakça}

Abbas, M., \& Raja, U. (2015). Impact of psychological capital on innovative performance and job stress. Canadian Journal of Administrative Sciences/Revue Canadienne des Sciences de l'Administration, 32(2), 128-138.

Ağca, Y., \& Döven, M. S. (2016). Liderlik davranışının örgütsel vatandaşlığa ve alt boyutlarına etkisi: perakende sektöründe bir araştırma. Süleyman Demirel Üniversitesi İktisadi ve İdari Bilimler Fakültesi Dergisi, 21(3).

Avey, J. B., Reichard, R. J., Luthans, F., \& Mhatre, K. H. (2011). Meta-analysis of the impact of positive psychological capital on employee attitudes, behaviors, and performance. Human Resource Development Quarterly, 22(2), 127-152.

Bandura, A., \& Walters, R. H. (1977). Social learning theory (Vol. 1). Englewood Cliffs, NJ: Prentice-hall.

Başar, U., \& Basım, H. N. (2018). Paradoksal Liderlik Modeli. Amme İdaresi Dergisi, 51(3), 121153.

Bono, J. E., \& Ilies, R. (2006). Charisma, positive emotions and mood contagion. The Leadership Quarterly, 17(4), 317-334.

Bulut, H., \& Meydan, C. H. (2018). Liderlik tarzlarının çalışanların ses verme davranışına etkisi: kamuda bir araştırma. Ankara Üniversitesi SBF Dergisi, 73(1), 223-244.

Coggins, E. D., \& Bocarnea, M. C. (2015). The Impact of Servant Leadership to Followers' Psychological Capital: A Comparative Study of Evangelical Christian Leader-Follower Relationships in the United States and Cambodia. Journal of Leadership, Accountability $\mathcal{E}$ Ethics, 12(4), 111-144.

Çetin, N. (2008). Kuramsal liderlik çözümlemelerinin ışığında, okul müdürlüğü ve eğitilebilir durumsal liderlik özellikleri. Pamukkale Üniversitesi Ĕgitim Fakültesi Dergisi, 23(23), 74-84.

Çetin, F., \& Basım, H. N. (2012). Örgütsel psikolojik sermaye: Bir ölçek uyarlama çalışması. Amme İdaresi Dergisi, 45(1), 121-137.

Çetin, F. \& Şeşen (2015). Genel Sistem Kuramı ve Örgüt Araştırmaları. H. Sözen, H. C., \& Basım, H. N. (Ed.) Örgüt kuramları. Ankara, Turkey: Beta Basım AŞ. 3. Baskı, İstanbul.

Detert, J. R., \& Treviño, L. K. (2010). Speaking up to higher-ups: How supervisors and skiplevel leaders influence employee voice. Organization Science, 21(1), 249-270.

Detert, J. R., \& Burris, E. R. (2007). Leadership behavior and employee voice: Is the door really open? Academy of Management Journal, 50(4), 869-884.

Demirağ, B., \& Çelik, M. (2019). Lider davranış özelliklerinin örgütsel bağlılık üzerindeki etkisi-The effect of leader behavior characteristics on organizational context. Mehmet Akif Ersoy Üniversitesi Sosyal Bilimler Enstitüsü Dergisi, 11(27), 1-21.

Ekvall, G., \& Arvonen, J. (1991). Change-centered leadership: An extension of the twodimensional model. Scandinavian Journal of Management, 7(1), 17-26.

Gül, H., \& Şahin, K. (2011). Bilgi toplumunda yeni bir liderlik yaklaşımı olarak transformasyonel liderlik ve kamu çalışanlarının transformasyonel liderlik algisı. Selçuk Üniversitesi Sosyal Bilimler Enstitüsü Dergisi, (25), 237-249.

Goldsmith, A. H., Darity, W., \& Veum, J. R. (1998). Race, cognitive skills, psychological capital and wages. The Review of Black Political Economy, 26(2), 9-21.

Gyu Park, J., Sik Kim, J., Yoon, S. W., \& Joo, B. K. (2017). The effects of empowering leadership on psychological well-being and job engagement: The mediating role of psychological capital. Leadership \& Organization Development Journal, 38(3), 350-367. 
Ismail, K., Khurram, W., Hussain, T., \& Jafri, S. K. A. (2011). Perceptions for transformational leadership, followers' psychological capital and intent to leave in Pakistan: An insight from medical and engineering sector. Interdisciplinary Journal of Research in Business, 1(8), 49-61.

Krasikova, D. V., Lester, P. B., \& Harms, P. D. (2015). Effects of psychological capital on mental health and substance abuse. Journal of Leadership \& Organizational Studies, 22(3), 280-291.

Kızrak, M., Bıçakçı, P. S., \& Basım, H. N. (2017). Öz-liderlik becerilerinde psikolojik sermayenin rolü: kamu çalışanları üzerine görgül bir araştırma. Business and Economics Research Journal, 8(4), 797-813.

Keleş, H. N. (2011). Pozitif psikolojik sermaye: tanımı, bileşenleri ve örgüt yönetimine etkileri. Organizasyon ve Yönetim Bilimleri Dergisi, 3(2), 343-349.

Keser, S., \& Kocabaş, İ. (2014). İlköğretim okulu yöneticilerinin otantik liderlik ve psikolojik sermaye özelliklerinin karşılaştırılması. Kuram ve Uygulamada Ĕ̆itim Yönetimi, 1(1), 1-22.

Li, Y., Castaño, G., \& Li, Y. (2018). Linking leadership styles to work engagement: The role of psychological capital among Chinese knowledge workers. Chinese Management Studies, 12(2), 433-452.

Luthans, F., \& Youssef, C. M. (2004). Human, social, and now positive psychological capital management: Investing in people for competitive advantage. Organizational Dynamics, 33(2), 143-160.

Luthans, F., Avolio, B. J., Avey, J. B., \& Norman, S. M. (2007a). Positive psychological capital: Measurement and relationship with performance and satisfaction. Personnel Psychology, 60(3), 541-572.

Luthans, F., Youssef, C. M., \& Avolio, B. J. (2007b). Psychological capital: Developing the human competitive edge. Oxford University Press, New York.

Luthans, B. C., Luthans, K. W., \& Avey, J. B. (2014). Building the leaders of tomorrow: The development of academic psychological capital. Journal of Leadership E Organizational Studies, 21(2), 191-199.

Luthans, F., Avolio, B. J., Avey, J. B., \& Norman, S. M. (2007). Positive psychological capital: Measurement and relationship with performance and satisfaction. Personnel Psychology, 60(3), 541-572.

McMurray, A. J., Pirola-Merlo, A., Sarros, J. C., \& Islam, M. M. (2010). Leadership, climate, psychological capital, commitment, and wellbeing in a non-profit organization. Leadership $\mathcal{E}$ Organization Development Journal, 31(5), 436-457.

Munyaka, S. A., Boshoff, A. B., Pietersen, J., \& Snelgar, R. (2017). The relationships between authentic leadership, psychological capital, psychological climate, team commitment and intention to quit. SA Journal of Industrial Psychology, 43(1), 1-11.

Özer, P. S., Topaloglu, T., \& Özmen, Ö. N. T. (2013). Destekleyici örgüt 1kliminin, psikolojik sermaye ile is doyumu 1liskisinde düzenleyici etkisi/The Moderating Effect of Supportive Organizational Climate on Psychological Capital and Job Satisfaction Relationship. Ege Akademik Bakış, 13(4), 437-447.

Özsahin, M., \& Zehir, C. (2011). Yüksek performanslı işletmelerde liderlik, girisim odaklılık ve örgütsel performans ilişkisi. Çanakkale Onsekiz Mart Üniversitesi Yönetim Bilimleri Dergisi, 9(2), 45-72.

Peterson, S. J., Balthazard, P. A., Waldman, D. A., \& Thatcher, R. W. (2008). Neuroscientific implications of psychological capital: Are the brains of optimistic, Hopeful, confident, and resilient Leaders Different? Organizational Dynamics, 37(4), 342-353. 
Pitichat, T., Reichard, R. J., Kea-Edwards, A., Middleton, E., \& Norman, S. M. (2018). Psychological capital for leader development. Journal of Leadership $\mathcal{E}$ Organizational Studies, 25(1), 47-62.

Rego, A., Sousa, F., Marques, C., \& e Cunha, M. P. (2012). Authentic leadership promoting employees' psychological capital and creativity. Journal of Business Research, 65(3), 429-437.

Seligman, M. E. (2002). Positive psychology, positive prevention, and positive therapy. Handbook of Positive Psychology, 2(2002), 3-12.

Sweetman, D., Luthans, F., Avey, J. B., \& Luthans, B. C. (2011). Relationship between positive psychological capital and creative performance. Canadian Journal of Administrative Sciences/Revue Canadienne des Sciences de l'Administration, 28(1), 4-13.

Tabak, A., Sığrı, Ü., \& Türköz, T. (2013). Öz liderlik ölçeğinin Türkçeye uyarlanması çalışması. Bilig, 67, 213-246.

Taşlıyan, M., \& Hırlak, B. (2016). Otantik liderlik, psikolojik sermaye, işten ayrılma niyeti ve çalışan performansı arasındaki ilişki: hemşireler üzerinde bir araştırma. Akademik Bakış Uluslararası Hakemli Sosyal Bilimler Dergisi, (56), 92-115.

Tengilimoğlu, D. (2005). Kamu ve özel sektör örgütlerinde liderlik davranışı özelliklerinin belirlenmesine yönelik bir alan çalışması. Elektronik Sosyal Bilimler Dergisi, 4(14), 1-16.

Topaloğlu, T., \& Özer, P. S. (2014). Psikolojik sermaye ile iş performansı arasındaki ilişkiye otantik liderliğin düzenleyici etkisi. Organizasyon ve Yönetim Bilimleri Dergisi, 6(1), 156-171.

Tüzün, İ. K., Çetin, F., \& Basim, H. N. (2014). The role of psychological capital and supportive organizational practices in the turnover process. METU Studies in Development, 41(2), 85103.

Xiang, H., Chen, Y., \& Zhao, F. (2017). Inclusive Leadership, Psychological Capital, and Employee Innovation Performance: The Moderating Role of Leader-Member Exchange. DEStech Transactions on Social Science, 2nd International Conference on Humanities Science, Management and Education Technology (HSMET 2017), Education and Human Science.

Xu, J., Liu, Y., \& Chung, B. (2017). Leader psychological capital and employee work engagement: The roles of employee psychological capital and team collectivism. Leadership E Organization Development Journal, 38(7), 969-985.

Wang, Y., Yuan, C., \& Zhu, Y. (2017). Coaching leadership and employee voice behavior: A multilevel study. Social Behavior and Personality: An International Journal, 45(10), 1655-1664.

Walumbwa, F. O., Avolio, B. J., Gardner, W. L., Wernsing, T. S., \& Peterson, S. J. (2008). Authentic leadership: Development and validation of a theory-based measure. Journal of Management, 34(1), 89-126.

Walumbwa, F. O., Peterson, S. J., Avolio, B. J., \& Hartnell, C. A. (2010). An investigation of the relationships among leader and follower psychological capital, service climate, and job performance. Personnel Psychology, 63(4), 937-963.

Yetgin, M. A. (2016). Örgütsel psikolojik sermaye ve destekleyici örgüt kültürünün otantik liderlikte rolü: görgül bir arastirma/The Role Of Psychological Capital And Supportive Organizational Culture On Authentic Leadership: An Empirical Study. Third Sector Social Economic Review, 51(2), 128-156.

Youssef, C. M. and Luthans, F. (2012). Psychological capital: Meaning, findings and future directions. The Oxford handbook of positive organizational scholarship, 1-23.

Yukl, G. (2012). Effective leadership behavior: What we know and what questions need more attention. Academy of Management Perspectives, 26(4), 66-85. 